Светлана Переволочанская

Российский государственный университет им. А.Н. Косыгина

Институт славянской культуры

Кафедра общей и славянской филологии

perevolochanskaja@yandex.ru
УДК 821.161.1.09"18"

https://doi.org/10.18485/slavistika.2020.24.1.12

Оригинални научни рад примљено 02.05.2020.

прихваћено за штампу 21.05.2020.

\title{
СМЫСЛОВЫЕ АКЦЕНТЫ ПУШКИНСКИХ ИМПРОВИЗАЦИЙ НА СЕРБСКИЕ МОТИВЫ
}

Статья посвящена семантическому анализу емкого в своей ассоциативности пушкинского слова, связанного с сербскими мотивами и сюжетами. Влияние фольклорного, культурного, исторического материала проявилось в создании самобытных образов, овеянных романтическим порывом. В творческой лаборатории поэта идет семантическая работа над словесным знаком: внутри поэтической единицы намечается движение и накопление смысла, который кристаллизуется в символе.

Ключевые слова: смысл, оним, моделирование, имплицитная многозначность, перифраза, символ, художественный образ.

The article is devoted to the semantic analysis of Pushkin's work, vast in its expressiveness and associativity related to Serbian motives and subject matters. The effect of folk, cultural, historical material is manifested in the creation of indigenous characters steeped in romantic flush. In his creative workshop the poet dedicates himself to the semantics of a word sign: inside a poetic unit, the movement and accumulation of the meaning is outlined, the meaning being crystallized in a symbol within the national, original linguistic continuum.

Keywords: meaning, onym, styling, implicit polysemy, periphrasis, symbol, art image.

Сербские мотивы в творчестве А. Пушкина занимают особое место. Они представлены в незначительном количестве в поэтических и прозаических произведениях. Но по своей значимости они уникальны и неповторимы для художественной, эстетической эволюции национального поэта. Они внесли свой вклад в формирование новой культурной парадигмы, гармонично соединившей черты европейского мышления и национальной самобытности в рамках романтической свободы, которая привела поэта к реализму.

Универсализм А. Пушкина, его «всемирная отзывчивость» проявились на фоне национальной гордости, нашедшей отражение в национальном романтизме, связанном с безграничной духовной свободой личности. Именно в этом контексте возникают сербские интонации и мотивы в его творчестве. Исследователи отмечают, что А. Пушкин едва ли не первый в России открыл мир сербской поэзии, корни которой уходят в общее историческое прошлое славянских народов. Известно, что в первой половине XIX в. в русской литературе возникает неподдельный интерес к национально-освободительному движению сербского народа против османского ига. В одной из публикаций «Вестника Европы» за 1808 г. отмечалось терпение и смирение «храбрых сербов», турецкий деспотизм привел в движение волю сербского народа: они, ведомые патриотическим чувством, изгнали ненавистных басурман. Опыт борьбы за нацио- 
нальную самобытность родственных славянских народов был интересен для русской культуры особенно с 20 -х годов в русле зарождающегося романтизма. Ассоциативность мышления молодого А. Пушкина, заряженного идеями нового течения, влияет на становление самобытного пушкинского слова: образы, связанные с героической историей сербского народа, провоцируют появление символических единиц, потенциально соотносимых с целым текстом. В данной статье импровизация рассматривается как авторская рефлексия на заданную (сербскую) тему с предполагаемой смысловой свободой ее развертывания. «Рефлексивность слова понимается как смыслоносная, смыслопорождающая и смыслоформирующая функция речемыслительной деятельности. Рефлексивность слова связана с направленностью, зарядом, напряжением и потенциалом действия выражаемой в нем мысли» (Карманова 2014: 5). М. Бахтин, указывая на потенциальную предикативность слова, определяет данную единицу как «аббревиатуру высказывания» (Бахтин 1979: 268).

Сербский колорит в языке А. Пушкина, обусловленный влиянием фольклорного, культурного, исторического материала, проявился в создании самобытных образов (яркой личности Карагеоргия) и народно-поэтических образов в Песнях западных славян, в заимствовании сербской символики как знаковых фактов, свидетельствующих о духовном единении славянских народов, в использовании ономастических единиц. Историческая проза А.С. Пушкина (История Петра), построенная на архивных материалах, изобилует ономастическими вкраплениями: упоминание представителей сербской истории воссоздает историческую ретроспективу балканского народа. Все эти факты, картины, образы служат для восприимчивого поэта декорациями, фоном, на котором рождается собственное действо.

Предметом поэтической рефлексии А. Пушкина является образ Карагеоргия, созданный в период южной ссылки. К личности руководителя Первого сербского восстания против Османской империи поэт обращался дважды. Мятежные образы вождя - романтически мрачный (в послании «Дочери Карагеоргия», 1820 г.) и реалистически противоречивый, экспрессивно-фольклорный (в «Песнях западных славян», 1834 г.) - разъяты временем и разным художественным мировосприятием поэта.

Дочери Карагеоргия, 1820 г. (Пушкин 1947: 148)

Гроза луны, свободы воин,

Покрытый кровию святой,

Чудесный твой отец, преступник и герой,

И ужаса людей, и славы был достоин.

Тебя, младенца, он ласкал

На пламенной груди рукой окровавленной;

Твоей игрушкой был кинжал,

Братоубийством изощренный...

Как часто, возбудив свирепой мести жар, 
Он, молча, над твоей невинной колыбелью

Убийства нового обдумывал удар

И лепет твой внимал, и не был чужд веселью!

Таков был: сумрачный, ужасный до конца.

Но ты, прекрасная, ты бурный век отца

Смиренной жизнию пред небом искупила:

С могилы грозной к небесам

Она, как сладкий фимиам,

Как чистая любви молитва, восходила.

Собственное имя Карагеоргий, употребленное в названии стихотворенияпослания 1820 г. (Дочери Карагеоргияㄱ), представляет собой экзотизм, содержательный объем которого определяется степенью знакомства с сербской историей. Первые сведения о братском славянском народе А. Пушкин почерпнул из разных источников. Во-первых, это собственные кишиневские наблюдения, связанные с рассказами о семье сербского вождя Карагеоргия, который после поражения сербского восстания поселился недалеко от Кишинева в 1814 г., а в 1817 г. был убит после возвращения на родину. Кишинев периода южной ссылки А. Пушкина был местом, куда стекались выходцы из балканских княжеств и где идеи национально-освободительной борьбы против ига Османской империи особым образом влияли на взгляды радикально настроенных людей. Во-вторых, литературным источником послужила изданная в 1810 г. книга Д.Н. Бантыш-Каменского «Путешествие в Молдавию, Валахию и Сербию» (Бантыш-Каменский 1910), содержавшая рассказ об убийстве Карагеоргием своего отца, который долгое время служил туркам и просил сына вернуться на родину. Для гордого и независимого Карагеоргия такой исход был равносилен рабству. Очевидно, последний источник в большей степени повлиял на поэта и послужил отправной точкой при описании противоречивого образа сербского героя.

Данный энциклопедический фон играет важную роль в структуре антропонима Карагеоргий, введенного в название в качестве концептуально значимой единицы. Это смысловой вектор, определяющий развитие читательской мысли. Особую значимость в этом процессе приобретает ономастический материал, обладающий высокой семантической потенцией. Это проявляется в том, что любое собственное имя обнаруживает связь с единичным понятием, максимально сливается с обозначаемым объектом, образуя так называемые фоновые знания. Но если этот объект (в нашем случае историческая личность Карагеоргия) явился неизвестным или малоизвестным для русского читателя XIX в., языковой знак становится почти пустым для адресата, потому что в нем весьма условно выражено лишь общее понятие, представленное как «имя вообще». В названии стихотворения оним Карагеоргий является информативно неполным

${ }^{1}$ В других редакциях стихотворения название имеет следующие варианты: Дочери Черного Георга (Кара Георга), Дочери Георга Черного. 
для русского языкового сознания того времени в силу отсутствия глубокого знания истории балканских народов. В его семантической структуре потенциально высвечиваются предельно абстрактные признаки - гендерная принадлежность (мужское имя) и определенный национальной колорит. Но и этот последний затушеван. Материальная оболочка лексемы свидетельствует о тюркском происхождении первой части имени: кара- в переводе с турецкого имеет значение «черный». Историческое имя Карагеоргий является прозвищем, которое скрывает славянскую принадлежность национального героя (наличие прозвища характерная особенность сербской антропонимии). Мотивированность данного именования очевидна: она строится на метафорическом переносе.

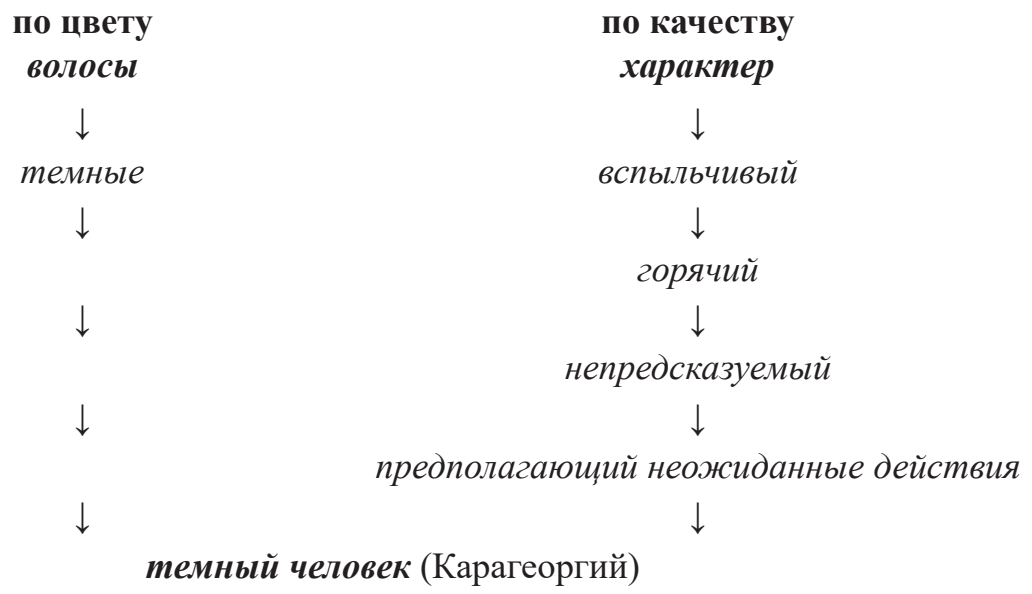

Истинное имя и фамилия данного исторического лица Георгий Пе́трович. В морфемной структуре второго компонента содержится типичный для большинства сербских фамилий суффикс -ОВИЧ-. Специфическим является и ударение (падает, как правило, на третий слог от конца): Йованович, Обрадович, Обренович. Становится очевидным то, что семантический намек на сербский национальный колорит в рассматриваемом ониме затушеван, скрыт за тюркским звучанием прозвища Карагеоргий.

Как видно, содержательный объем данного имени, связанный с энциклопедической информацией, открытых признаков единичного понятия почти не обнаруживает: возникают только отдельные ассоциации с историей балканских народов. Но в самом тексте происходят невероятные трансформации: ономастический знак, заявленный в названии и высвеченный некоторым набором абстрактных признаков, семантически конденсируется и находит выражение в бесконечности смысловой перспективы в тексте.

Направление смыслового развития в послании задает именно название, в котором имя Карагеоргий как зависимый компонент подчинительной связи образует сцепление с опорной лексемой дочь. Идеализированный, романтически поэтизированный образ дочери Карагеоргия, плод пушкинской фантазии, возник на основе различных устных преданий, услышанных им от сербов во время южной (кишиневской) ссылки. Притяжение двух поляризованных лексических 
единиц определяет последующую диалектику смыслового противоборства. Здесь вступает в силу механизм моделирования особого рода текста, характеризующегося пушкинским лаконизмом, с одной стороны, и семантической емкостью, смысловой многозначностью лексических единиц, с другой.

Сопряжение нескольких смысловых планов приводит к намеренной многозначности высказываний. Наиболее часто встречающийся тип - имплицитная многозначность, которая представляет собой некий подтекст, моделируемый смысл, по эстетической, литературной значимости более важный, чем смысл эксплицитный. Актуализация семантических признаков имени сербского героя протекает в области ассоциаций. Вербальные ассоциации есть «ассоциации смыслов или более широко - употреблений слов» (Леонтьев 1965: 185). Процесс актуализации приводит к появлению нового значения, новой стилистической и эмоциональной окраски собственного имени.

Романтический образ Карагеоргия есть отражение внутреннего противоречия: преступник и герой (сумрачный, ужасный), одухотворенный борец за свободу. Свобода определяет ту цель, которая снимает с героя перед историей всякую ответственность за свои деяния. А. Пушкин, как истинный романтик, соединяет в этом образе реальное и идеальное, выражающееся в диалектически сопряженных смыслах. Внутри заданной формы взаимодействуют и заряжают семантической энергией представленный образ лексические компоненты бинарной оппозиции: преступник - герой.

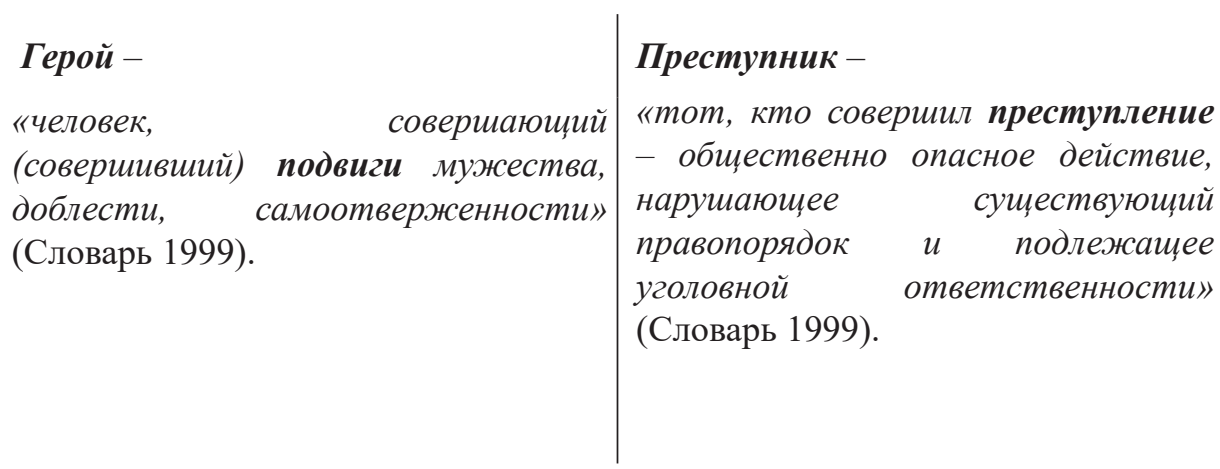

Общие семы для данных лексем можно представить в виде цепочки имплицитно детерминированных семантических признаков: 'совершение действия' $\rightarrow$ 'по отношению к кому-либо' $\rightarrow$ 'общественно значимые' $\rightarrow$ 'способность преодолеть препятствие' $\rightarrow$ 'готовность к самопожертвованию' $\rightarrow$ 'вмешательство в обычный, привычный ход событий' $\rightarrow$ 'нарушение привычного хода событий' $\rightarrow$ 'оправдание действий поставленной целью'.

Больше семантически близких признаков нет, дальше имплицитная цепочка расходится в смысловой антонимии: 


$\begin{array}{lll}\text { 'самоотверженный поступок' } & \leftrightarrow & \text { 'опасное для других действие' } \\ \text { 'на благо других' } & \leftrightarrow & \text { 'причиняющее другим зло, несчастье' } \\ \text { 'ответственность за других' } & \leftrightarrow & \text { 'снятие с себя ответственности' } \\ \text { 'вознаграждаемое' } & \leftrightarrow & \text { 'наказуемое' } \\ \text { 'душевная стойкость' } & \leftrightarrow & \text { 'душевное раскаяние' }\end{array}$

Преступник (чудесный отеи) и герой (свободы воин, покрытый кровию святой) // достоин ужаса людей и достоин славы - соединяются в пары, где компоненты семантически противоборствуют и в то же время детерминируют друг друга. Данный смысловой конгломерат подпитывается целым набором перифраз: гроза луны, свободы воин, свирепой мести жар, убийства нового удар, бурный век отца. Все они углубляют и расширяют смысловое поле героического восприятия исторической личности. Перифразы: гроза луны, свободы воин в данном случае используются как индивидуальное обозначение героя, имеют оценочный характер, выражают отношение поэта к своему герою.

Перифрастические обороты именного типа, представляющие собой эквиваленты имен, привычны в пушкинском поэтическом обиходе. Специфику данного употребления составляет необычный выбор опорного члена перифразы: вместо привычных для классицистических штампов существительных $\mathrm{cblh,} n u$ томеи, наперсник, друг, баловень, любовник, ленивеи, шалун, наездник и др. А. Пушкин, использует семантически значимые гроза и воин. Они своеобразный смысловой ориентир, позволяющий уловить независимо от контекста общее направление перифразы. К тому же стилистическая маркированность лексемы воин как высокое определяет ее доминирующее положение в смысловом ряду, ее аксиологическую доминанту для всего текста. В данной лексеме в большей степени представлена сема 'высокого долженствования'. Определяющий член перифразы, выраженный лексемами с символическим наполнением (в родительном падеже), сужает объем понятия до зримого исторического образа.

Лексемы луна и свобода образуют смысловую пару. Луна, как символ дуалистичности, проявляющийся в цикличности - жизнь и смерть, связана с мистическими, мифологическими представлениями, в то же время этот символ привязан к религиозному контексту: луна/месяц - символ исламского могущества, он противопоставлен христианскому кресту. Тогда лексема свобода (в значении «независимость») становится тоже символом с антонимическим семантическим ракурсом - символом борьбы за христианскую веру (против османского ига). Освещенность лексем такой символической природой распространяется на последующие строки, энергетически поглощает семантическое содержание лексем герой и преступник. Их символическая деформация приводит к смысловому движению: содержательно данные единицы, изначально противопоставленные, могут толковаться как синонимичные с совпадением смысловых объемов.

Представленные в приведенном выше ряду перифразы: свирепой мести жар, убийства нового удар, бурный век отцуа - выступают в функции наиме- 
нования и обобщения. Границы перифраз именного типа расширяются за счет введения в них определений-эпитетов, которые, будучи стилистически маркированными, несут в себе авторскую оценку. Интересно с точки зрения семантического масштабирования посмотреть на другие редакции пушкинского текста стихотворения, где наблюдаются колебания в выборе как опорного слова перифразы, так и определяющего члена (существительного в родительном падеже) и определений-эпитетов.

\section{Последняя редакция \\ - свирепой мести жар -}

$$
\begin{aligned}
& \text { Другие редакции } \\
& \text { свирепый сердца жар, } \\
& \text { мятежный сердца жар }
\end{aligned}
$$

В данных примерах обнаруживается не только замещение лексем, но и изменение характера подчинительной связи: жар $\rightarrow$ мести $\rightarrow$ свирепой // свирепьій (мятежный) $\leftarrow$ жар $\rightarrow$ сердияа.

\section{- убийства нового удар -}

злодейства дерзкого удар

В первом случае более точно номинируется действо: убийство - «лишение жизни кого-либо», а определение указывает на нечто иное, ранее никогда не случавшееся. Во втором случае действие носит неопределенный характер: злодейство - «любое тяжкое преступление, злодейский поступок» (то есть не обязательно убийство); определение подчеркивает его (действия) отчаянность и рискованность.

- бурный век отца грозну (страшну) жизнь отца
отца мятежный (преступный) век

Определения-эпитеты отличаются семантически и стилистически: npecmynный - «исполненный преступлений»; мятежный (традиционно-поэтическое) - «тревожный, неспокойный; мятущийся» [ср.: (Даль) - «относящийся к народному волненью»]; бурнылй - «крайне неспокойный». Последнее имеет больший содержательный объем по сравнению с первыми определениями-эпитетами. Краткие формы синонимичных прилагательных грозный в значении «суровый», страшныци в значении «опасный» стилистически снижены, их образность заимствована из арсенала народно-поэтических средств, хотя усеченность форм может быть следствием метрических особенностей стиха.

Данный лексический разброс в редакциях послания свидетельствует о рефлексии пушкинской мысли, которая в творческом нетерпении ищет точности, ясности в выборе лексической единицы, пытается постичь истинную сущность слова в его семантической глубине и непредсказуемости. В этой работе интуиция поэта почти никогда не подводит. Выбор представленных перифраз является тому подтверждением. 
Лексемы век и жизнь (век отцуа / жизнь дочери) в смысловом отношении предельно нагружены. В них по-разному организуется время: оно разделено на семиотическое время и на время физической реальности. Лексема век в данном контексте может быть маркирована как высокое, имеет ограничения в рамках начало - конец, что в итоге связывает ее с идеей исторического бессмертия. Семиотическая значимость лексемы в данном контексте очевидна. Она вписывается в парадигму век - мгновенье (вечность - миг, вечность - мгновение). Лексема жизнь стилистически нейтральна, значение ее проявляется в рамках общеязыкового понимания - «время существования от рождения до смерти», а более широко - «земное бытие». В отличие от семантики слова век в лексеме жизнь время представлено как длящееся, мыслимое, как нечто, пока не ограниченное какими-либо пределами, но стремящееся к своей предельной точке. В этом смысле оно анизотропно, необратимо, вектор его движения направлен только в одну сторону. Данная лексема вписывается в другую парадигму жизнь - смерть (бытие - небытие, бытие - смерть). Разделенность времени, представленная в анализируемых лексемах, позволяет рассматривать их в символическом контексте смерть - бессмертие (преходящее-вечное).

Семиотичность времени зафиксирована в границах перифрастического оборота (бурный век отца), где оно скреплено рамками лексической устойчивости. Физическая осязаемость времени размыта в текстовом пространстве стихотворения: лексема жизнь удалена от лексемы дочь, употребленной только в названии, и близка к ее дейктической замене $(m b l)$ с уточняющим определением (или обращением) в постпозиции (прекрасная), что создает смысловое ощущение развернутости времени. Синонимически связанные лексемы век и жизнь в контексте трансформируются в антонимическую пару (век отияа, но жизнь дочери) по признакам 'завершенный, законченный' и 'длящийся, продолжающийся'.

Полученная семантическая схема накладывает свой отпечаток на смысловое поле стихотворения: оппозиционно выстраиваются тематические парадигмы, провоцирующие намеренную смысловую двуплановость. Смысловое развертывание осуществляется на базе разнообразного лексического материала в следующих оппозициях:

\section{Omeu}

рукой окровавленной

кинжал, братоубийством изощренный

убийства нового удар

сумрачный, ужасный

бурный век отца

могила грозная

\section{Дочь (младенец)}

ласкал

игрушка

над невинной колыбелью

прекрасная

смиренная жизнь

сладкий фимиам,

чистая любви молитва

Разрешение смыслового конфликта - в последних строках: смиренной жизнию. пред небом искупила // как чистая любви молитва, восходила. Тематическая 
завершенность определяется композицией: символические единицы, расположенные в первой и последней строках, делают организацию стихотворения завершенной как структурно, так и тематически.

Последние строки - откровение, к которому приходит А. Пушкин, пока на уровне манифестации романтической идеи: он ищет обоснование действий своего героя и находит причину в справедливости той высокой цели, которая и оправдывает средства. Цель эта освящена мыслями о свободе, независимости и освобождении сербского народа, о его национальном самосознании. Борьба протекает внутри заданной формы образа романтического героя. Она и способствует диалектическому движению внутренней природы образа Карагеоргия, а поэтому он поэтически привлекателен.

Смысловая интрига должна была бы разрешиться в семиотическом пространстве - в сопряжении символов: символа исламской веры (луна / месяи) и символа христианской веры (свобода / молитва). Лексический фон последних строк подталкивает рефлексию читательской мысли в область религиозного мировоззрения. Но стилистически и семантически значимые лексемы: искупить пред небом (в других редакциях - перед Богом) в значении «заслужить прощения», восходить к небесам в значении «возноситься» (для сравнения: молитвы восходят к небесам - В. Даль) - имеют прямое отношение к смиренной жизни, а не к сакральному таинству молитвы. К тому же последнее синтаксически вуалируется сравнительными оборотами, они предполагают только уподобление по общему для сопоставляемых объектов признаку - как сладкий фимиам, как чистая любви молитва. Соседство лексем фимиам - молитва в поэтических строках провоцирует наложение и смещение значений. Изначально обе единицы связаны с религиозной обрядовостью. Но эпитет сладкий снимает семантический шлейф ритуальности и обнажает значение «восторженная похвала», сходное с фразеологизмом курить фимиам. Лексема молитва, заключенная в границы перифразы чистая любви молитва, меняет сакральную страту на более сниженную, связанную с обращением к человеческому чувству.

Таким образом, христианская символика в творчестве молодого поэта ближе к романтической мистификации, в ранних романтических произведениях он еще «не дотягивает» до глубокого постижения сущности христианской духовности. Им еще не освоены «спокойствие и уединение» молитвы, он еще только в начале пути к пониманию основ православного аскетизма, зиждущегося на духовном субстрате исихазма. Реалистичность и исключительность героя, овеянного революционным энтузиазмом, в рамках эмоционально-приподнятого мироощущения автора смещает символический фон в область гражданских чувств. Лексический материал, семантическая сфера послания свидетельствуют о том, что в творческой лаборатории поэта намечается пока неясное движение к слову-символу, которое найдет свое завершение в поздней лирике в русле реализма, где новый образ Карагеоргия будет явлен в «Песнях западных славян».

Анализ отдельной поэтической единицы - текста пушкинского послания позволил увидеть процесс смыслового «оборачивания» словесного знака, условия перехода от знака к символу, обращенному к архетипам национального сознания, религиозным истинам, языческим прообразам, концептуальным еди- 
ницам. Конкуренция между неявленным и явленным спровоцирована «романом сознания с языком» (Гоготишвили 2006: 571). Такому образу более всего соответствует семантически формирующееся пушкинское слово, емкое в своей предметности, экспрессивности и ассоциативности, предполагающее связь с литературными, национальными и интернациональными «темами», сюжетами, по этой причине насыщенное ретроспективным богатством эстетических и культурных универсалий.

\section{Использованная литература}

Бантыш-Каменский, Дмитрий Н. Путешествие в Молдавию, Валахию и Сербию. Москва: В Губернской типографии у А. Решетникова, 1810.

[Bantysh-Kamenskiū, Dmitriı̌ N. Puteshestvie v Moldaviiư, Valakhiiû i Serbiiû. Moskva: V Gubernskoĭ tipografii u A. Reshetnikova, 1810]

Бахтин, Михаил М. Эстетика словесного творчества. Москва: Искусство, 1979.

[Bakhtin, Mikhail M. Ėstetika slovesnogo tvorchestva. Moskva: Iskusstvo, 1979]

Гоготишвили, Людмила А. Непрямое говорение. Москва: Языки славянских кульTyp, 2006.

[Gogotishvili, Liudmila A. Nepriamoe govorenie. Moskva: Tazyki slaviānskikh kul'tur, 2006]

Карманова, Зоя Я. Феноменологические аспекты содержательной структуры слова. Калуга: Издательство «Эйдос», 2014.

[Karmanova, Zoiā Iâ. Fenomenologicheskie aspekty soderzhatel'noĭ struktury slova. Kaluga: Izdatel'stvo «E்īdos», 2014]

Леонтьев, Алексей А. Слово в речевой деятельности. Монография. Москва: Изд-во AH CCCP, 1965.

[Leont'ev, Alekseǐ A. Slovo v rechevoř deiâtel'nosti. Monografiia. Moskva: Izd-vo AN SSSR, 1965]

\section{Источники}

Даль, Владимир И. Толковый словарь живого великорусского языка $<\mathrm{https}: / /$ www. slovardalja.net/ > 08.04.2020.

[Dal', Vladimir I. Tolkovyǐ slovar' zhivogo velikorusskogo iāzyka <https://www. slovardalja.net/>08.04.2020]

Пушкин, Александр С. Полное собрание сочинений в 16 т. Т.2, кн.1. Москва; Ленинград: Изд-во АН СССР, 1947.

[Pushkin, Aleksandr S. Polnoe sobranie sochineniĭ v 16 t. T.2, kn.1. Moskva; Leningrad: Izd-vo AN SSSR, 1947]

Словарь русского языка: В 4-х т. / АН СССР, Ин-т рус. яз.; Под ред. А. П. Евгеньевой. Москва: 1999.

[Slovar' russkogo iâzyka: V 4-kh t. / AN SSSR, In-t rus. iâz.; Pod red. A. P. Evgen'evoĭ. Moskva: 1999] 


\section{Светлана Переволочанска}

\section{СМИСАОНИ АКЦЕНТИ ПУШКИНОВИХ ИМПРОВИЗАЦИЈА ПО СРПСКИМ МОТИВИМА}

\section{Резиме}

Рад има за тему семантичку анализу посланице А. Пушкина „Карађорђевој кћери“. У првој половини XIX века српски фолклор у различитим европским земљама добија веома велики значај: у Француској њиме је заокупљен Проспер Мериме, у Пољској - Адам Мицкјевич. А. С. Пушкин као један од првих открива свет српске поезије. Његова „отвореност ка целом свету“ испољила се у контексту националног поноса, који је нашао одраз у националном романтизму, везаном за бескрајну духовну слободу личности. Управо у овом контексту појавиле су се српске интонације и мотиви у његовом стваралаштву. Српски свет ce А. Пушкину указао као богата историјска, културна, уметничка парадигма. Семантичка анализа песме указује на то да енциклопедијски фон игра важну улогу у структури антропонима Kapaђорђе, који се може посматрати као концептуално значајна јединица текста. Ово је смисаони вектор који одређује развој мисли читалаца. Посебан значај у овом процесу добија ономастички материјал, који поседује високи семантички потенцијал. Песник се обраћа српском фолклору у покушају да обнови традиционалну романтичарску изражајност. Дубински садржаји код А. Пушкина налазе одраз у спољашњем: национални, словенски дух није оваплоћен у апстрактној копији, лику-схеми, он попут мозаика састављеног од мноштва појединачних ситних детаља пружа визуелну, осетну, целовиту, стилски оправдану представу о лику Карађорђа. Дата песма сведочи о дубоком семантичком раду песника над вербалним знаком: смисаона енергија речи кристалише се као симбол. Анализа појединачне поетске јединице омогућава да се види процес смисаоног „померања“ вербалног знака, условног прелаза од знака ка симболу, усмереног ка архетиповима националне свести, религијским истинама, паганским архетиповима, концептуалним јединицама.

Кључне речи: смисао, оним, моделирање, импликативна многозначност, перифраза, симбол, уметнички лик. 